Наталія Клименко

ORCID: orcid.org/0000-0002-4407-4306

DOI 10.31558/1815-3070.2021.41.27

УДК $811.161 .2 ’ 282.2 ’ 373$

\title{
ЛЕКСИЧНА ПОЛІСЕМІЯ В УКРАЇНСЬКИХ СХІДНОСТЕПОВИХ ГОВІРКАХ
}

Статтю присвячено аналізу динаміки семантичної структури слова в східностепових говірках Донеччини, що є однією з найхарактерніших рис українських говірок пізнього творення, розташованих на периферії діалектного континууму. Виявлено полісемічні східностепові номени та з'ясовано їх статус у системі української діалектної лексики. Розглянуто продуктивні зміни семантичної структури діалектних лексем, щзо спричинили ї̈ розширення метафоричне й метонімічне перенесення. 3'ясовано причини й шляхи розгалуження семантичної структури слова в обстежуваних говірках. Відзначено роль експресивної очінки при модифікачії семантичної структури діалектного слова в новостворених українських говірках Донеччини.

Ключові слова: сема, семантична структура слова, полісемія, метафоричне перенесення, метонімічне перенесення, синекдоха, діалектна лексика, украӥнські східностепові говірки.

Постановка наукової проблеми. Вивчення семантики діалектного слова дотепер залишається одним із найактуальніших завдань сучасного мовознавства. Не можна не погодитися 3 думкою П. Ю. Гриценка, що «семантика діалектного слова за його евристичною цінністю і складністю для пізнання має бути, хоча й досі не стала, окремим об'єктом дослідження чи хоча б рівноправним при аналізі змісту і форми слова, а не традиційно периферійним» (Гриценко 1990: 150).

Аналіз досліджень цієї проблеми. Про необхідність розробки проблем діалектної семасіології неодноразово йшлося в роботах таких лінгвістів, як: С. Б. Бернштейн, М. І. Толстой, Й. О. Дзендзелівський, В. С. Ващенко, П. Ю. Гриценко, В. Д. Старичонок, Г. Л. Аркушин та ін. Дослідники справедливо наголошували на тому, що розвиток лексичної системи будь-якої мови передбачає зміни як плану вираження, так і змісту слова (Русанівський 1988: 62; Гриценко 1990: 150). Щодо змін у формі вираження (лексичній системі мови), то, на думку О. О. Тараненка, «особливо «пощастило» територіально-діалектним особливостям та лексиці давніх народних промислів» (Тараненко 1973: 92), оскільки на сьогодні українська діалектологія налічує вже чимало розвідок, присвячених вивченню окремих тематичних груп лексики як на матеріалі старожитніх, так і новостворених українських говорів. Натомість семантика (змістова сторона діалектної мови) потребує докладного вивчення, оскільки «вся складна проблематика семантичного поля лексеми залишалася поза спостереженнями» (Бернштейн 1986: 4).

На сучасному етапі розвитку української діалектології питання семасіології на матеріалі різних груп лексики були порушені в працях Г. Л. Аркушина (Аркушин 2014), Г. І. Гримашевич (Гримашевич 2004), Т. М. Тищенко (Тищенко 2008) та інших дослідників. Однак дотепер немає чіткого уявлення про семантичні зрушення, що відбуваються в новостворених українських говірках, зокрема східностепових говірках Донеччини, що й зумовлює актуальність такого дослідження. Для повноти відображення різноманітних змін у семантичній структурі діалектної лексики видається цілком умотивованим найдокладніше вивчення семантики діалектного слова в конкретній говірці, що дозволить помітити повторювані риси загального, установити типові моделі семантичних зрушень у різних лексемах та в майбутньому сформулювати загальні закони семантичного розвитку української діалектної лексики. 
Новизна дослідження полягає у спробі проаналізувати зміни в семантичній структурі діалектного слова в новостворених українських говірках Донеччини, пов'язані з метафоричним та метонімічним перенесеннями найменувань.

Метою статті $\epsilon$ аналіз явища лексичної полісемії в українських східностепових говірках. Досягнення сформульованої мети передбачало виконання таких завдань: виявити багатозначні номени в лексиці говірок Донеччини; визначити їх семантичну структуру; охарактеризувати основні типи переносних значень; з'ясувати причини й шляхи розвитку (модифікації) семантичної структури слова в досліджуваних говірках; виявити статус багатозначних східностепових номенів в системі української діалектної лексики.

Об'єктом дослідження в цій роботі є діалектна лексика українських говірок Донеччини. Лексична система східностепових говірок обрана не випадково. «Генетична неоднорідність новоствореного діалектного континууму викликала нові системні явища на всіх говіркових рівнях східностепових говірок, типовою ознакою яких стала варіативність, а також набуття нових функцій мікросистемами протиставних діалектних явищ, зокрема лексичних та граматичних, які склалися на території старожитніх говорів» (Фроляк 2013: 7).

Предметом вивчення є лексична полісемія, властива українським східностеповим говіркам Донеччини, як свідчення варіювання семантичної структури лексики новостворених українських говорів. Аналіз цього явища дозволить простежити напрями й характер семантичних змін лексики зазначеної частини українського діалектного континууму, яка виявляється особливо нестійкою через неоднорідність походження східностепових говірок, розташування останніх на периферії українського діалектного континууму, функціонування в поліетнічній ситуації тощо.

Ідеться про аналіз багатозначності як свідчення ускладнення семантичної структури лексеми в межах говірки як системи. Це видається важливим для побудови в перспективі наддіалектних моделей семантичної структури конкретних діалектних назв (на матеріалі різних східностепових говірок), уможливить урахування й паритетність усіх сем, дозволить окреслити в загальних рисах напрями семантичних змін. Однак лише в конкретних говірках можна простежити реальні семантичні зрушення, мотивовані «як потенційними можливостями вихідного семантичного комплексу, так і діянням типових панлокальних моделей семантичної деривації» (Гриценко 1990: 159). Усе вищезазначене не ставить під сумнів тезу про те, що «реальну семантичну структуру лексеми - як про репертуар сем і їх архітектоніку (набір певним чином упорядкованих значень) - можна говорити лише на рівні окремої говірки» (Гриценко 1990: 153).

Матеріал, використаний у статті, записано в діалектологічних експедиціях у населених пунктах Донецькій області протягом 1998-2013 рр. У більшості населених пунктів матеріал зібрано самим автором, однак до аналізу залучено також діалектні матеріали, записані аспірантами й студентами філологічного факультету Донецького національного університету імені Василя Стуса (тоді - Донецького національного університету). Основним методом дослідження явища лексичної полісемії в східностепових говірках $є$ описовий метод 3 використанням прийомів моделювання семантичної структури діалектної лексики.

Теоретична й практична цінність результатів дослідження полягає в тому, що аналіз лексичної багатозначності в українських східностепових говірках дозволяє простежити семантичну місткість діалектного слова в новоствореній говірці; основні тенденції розвитку семантичної структури лексики в українських східностепових говірках пізнього творення, розташованих на периферії українського діалектного континууму; закласти потенційні значення у створення наддіалектної моделі - інваріантної семантичної структури аналізованої лексики, що дозволить вичленувати типові й спорадичні семантичні зміни в лексичній системі української діалектної мови.

Дослідження лексичної системи новостворених говірок Донеччини засвідчило, що однією 3 найхарактершіших ознак цих говірок $є$ зміни в семантичній структурі лексем, відомі іншим українським говорам (Кушмет 2014: 17; Клименко 2019: 81). Розглянемо докладніше 
такі зміни, найпоширенішою з яких виявляється розширення семантичної структури слова. Маємо справу з перенесенням назви з одного предмета на інший на основі подібності між цими предметами або якихось зв'язків між ними. Залучений до аналізу фактичний матеріал дозволяє як найбільш продуктивний спосіб визначити метафоричне перенесення. Така полісемія може бути як внутрішньосистемною, так і позасистемною, тобто виникати при перенесенні назви з однієї терміносистеми до іншої (Шматко 2014: 77-78).

Серед діалектної лексики східностепових говірок знаходимо слова вузьколокального вжитку, що стали такими через розвинення додаткового значення на основі подібності між певними реаліями. Причому ця схожість може бути різною: за формою, за кольором, за призначенням, за враженням, за поведінкою, за функцією тощо.

Так, перенесення назви на основі функціональної подібності між денотатами можна простежити, характеризуючи семантичну структуру східностепових лексем: ма́мка - крім загальновідомого значення 'мати' (СУМ 4: 615) набуває в частині східностепових говірок, розташованих на узбережжі Азовського моря, ще й значення 'велика хижа риба роду окунеподібних, яка містить багато ікри й живе в прісній та морській воді’ (Бз НА); то́рбочка - крім значення 'вид дорожнього мішка, що його носять звичайно за плечима', відомого всім східностеповим говіркам, як і літературній мові (СУМ 10: 200), подекуди набуває значення 'кишеня, яку жінки носили під фартухом для зберігання дрібних речей’ (Роя), тобто може входити й до семантичного поля 'елементи жіночого поясного одягу' разом з номенами калиета́, гамáн, гамане́u’. Порівняймо: калиета́ - крім значення 'заст. торба для грошей', у говірці села Шахова Ясинуватського району Донецької області також побутує зі значенням 'кишеня, яку жінки носили під фартухом для зберігання дрібних речей' (Шах Яс); гама́н - у деяких східностепових говірках має семантичну структуру, що охоплює значення: 'сумочка для грошей', 'кисет', 'бумажник' та 'кишеня, яку жінки носили під фартухом для зберігання дрібних речей' (Ів Бахм, РЯ Кост, Ол-К Кост, Вір Кост, Кл Бахм, Мик Г, Воздв, ЗК Добр, Перв Яс, Оп Яс, Красногор); гамане́u' 'т. с.' (Розд Бахм, Зв Бахм, Сів, Кр Ст).

3-поміж інших видів метафоричних перенесень слід відзначити перенесення на основі подібності за формою. Наприклад, назва $к u^{e} c$ 'л'áк у досліджуваних говірках зафіксована нерідко у двох значеннях - 'згусле кисле молоко' і 'кефір, густий поживний напій, який виготовляють із молока спиртовим і молочнокислим бродінням' (Красногор, С, Бл Амв, Корсунь, Петр П), друге з яких $\epsilon$, очевидно, перенесенням назви з одного предмета на основі подібності за формою. Порівняймо: а киес 'л'а́к ти не купл'а́ла / йак була́ в магаз 'iн'i (?) // (C)

Назва дошч'е́ч'ка в деяких східностепових говірках (Новотр В, С, Вільне, Шевч ВН) використовується на позначення 'примітивної дошки рамкового вулика, що підставляється до вулика й на неї прилітають бджоли', 'звичайної маленької дощечки з дерева, призначеної для майстрування з неї чого-небудь', ‘звичайної дерев'яної дощечки, що використовується на кухні для нарізання будь-яких продуктів'. Порівняймо: це мале́н'ка дошче́чка / йака́ n’iдставл'а́йеu': а до л'отка́ // пчо́ли прил 'iта́йуm' / c'idáŭym' на не́йі i по н'ій зала́з’ат' у

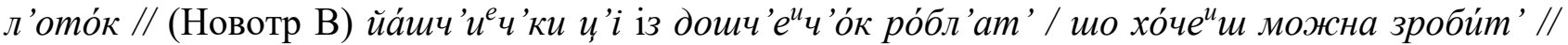

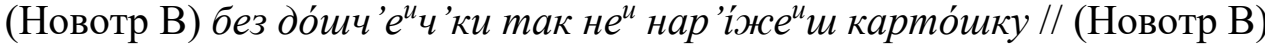

Назва шийа у говірці села Орлинське Ясинуватського району вживається на позначення як 'частини тіла людини та більшості тварин, що з'єднує голову з тулубом', так і 'похилого спуску до льоху'. Порівняймо: диеви́с'а / на шиийі / ступ 'е́н 'ки крут 'i / не ступи́ ми́мо // (Ор Яс)

Номен йіжач'óк використовується в говірці смт Корсунь м. Снакієве як лексичний репрезентант сем 'невеличка тварина-ссавець, спина й боки якої вкриті твердими голками' (укр. літ. 'т. с.' (СУМ 4: 59)) і 'металевий прилад із загнутими кінцями для витягання затонулих відер з дна колодязя’ (Корсунь). Порівняймо: йа зна́йу / шч’o ще ко́шка / но пона́шому йіжач'óк // (Корсунь)

Назва бана́н у складі описової номінативної конструкції украйін'с 'кий бана́н використовується в говірці н.п. Донське Волноваського району Донецької області не тільки на позначення довгастого солодкуватого плоду пальмоподібної тропічної рослини з величезним 
листям, а й також як репрезентант семи 'ревінь'- порівняймо укр. літ. ревінь 'трав'яниста багаторічна рослина з великим листям і товстим корінням; використовується в кулінарії та народній медицині' (СУМ 8: 471). Порівняймо: ду́мали / шо то хр 'ін / а то не ир 'ін / а p'е́в 'ен' був / ие нази ва́йут' у нас украйін'с 'ким бана́ном / бо його́ неи ли́с'm'a йіd’ám' / а сто́впчиек / в’ін таки́й киеслува́тий // (Кушмет-Бодаммер 2017: 93).

До метафоричних видів перенесень за формою слід назвати й перенесення в дієслівних номенах. Наприклад, у говірці с. Слизаветівка Мар'їнського району Донецької області слово ви́с'в'ати $m$ ' функціонує не тільки як репрезентант сем 'надавати кому-небудь духовне звання' та 'виконувати певний обряд, внаслідок якого хто- або що-небудь очищається', а $є$ й лексичним маніфестантом семи 'зробити кому-небудь суворе зауваження, догану'. Уживання слова ви́с'в 'ати $m$ ' у значенні 'зробити кому-небудь суворе зауваження, догану' детерміну-

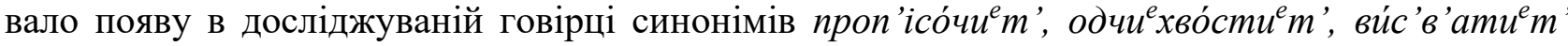
$(\mathrm{C} \mathrm{M})$.

До полісемічних відносимо й номен матр'о́шка, що побутує в деяких східностепових говірках на позначення не тільки семи 'дерев'яна мальована лялька, в яку вставляються такі ж ляльки меншого розміру' - порівняймо рос. матрёшка 'полуовальная полая разнимающаяся посередине деревянная расписная кукла, в которую вставляются другие такие же куклы меньшего размера' (Ожегов 1999: 852). У говірці села Єлизаветівка Мар'їнського району Донецької області назва матр'о́шка функціонує ще й зі значенням 'хустка, переважно з тонкої вовни, квітчаста, яку жінки старшого віку пов'язують, як на ляльці'. Як бачимо, вторинне, похідне значення слова в лексиці досліджуваної говірки може розвиватися й у лексемах, що потрапили до словника говірки внаслідок активних міждіалектних контактів. Периферійне розташування східностепових говірок, близькість російських говірок, безперечно, $є$ причиною функціонування в українських говірках Донеччини значної кількості росіянізмів. В українській говірці вони вже не сприймаються як запозичені, а тому їх семантична структура зазнає такого варіювання, як і в інших власне українських назвах. Це спостерігаємо й у номені зага́шни $\kappa_{\kappa}-$ порівняймо: у говірці н. п. Є М ця лексема функціонує зі значеннями 'місце, де щось зберігається' та 'закутки у будовах господарського двору, де зберігаються інструменти та будівельні матеріали'. У російській мові ця лексема є просторічною й має значення 'місце (яу правило, в одязі, на собі), де щось зберігається, заховано' (Ожегов 1999: 483).

Іншу мікрогрупу переносних метафоричних найменувань, що $є$ вторинними номенами в східностепових говірках унаслідок перенесення назви з одного предмета на інший за призначенням, утворюють назви: кобура́ - у східностепових говірках це слово може бути не тільки репрезентантом сем 'шкіряна торбина біля кавалерійського сідла' i ‘футляр для пістолета', як в інших українських говорах та літературній мові (СУМ 4: 201), а й семи 'капюшон' (С М). Порівняймо: йа дошч'ý не бойу́c' / на голов'í кобура́ / сама́ в бу́р'u’’i / i пор 'áдок // (С M).

Номен бурка в обстежуваних говірках характеризується розлогою семантичною структурою: '1) старовинний верхній довгополий чоловічий одяг 3 домотканого грубого сукна 3 відлогою; 2) накидка без рукавів з відлогою від дощу; 3) брезентовий плащ 3 відлогою' (Омельченко, Клименко 2006: 16). Порівняймо значення слова бу́рка в літературній мові: 'повстяний безрукавний плащ або накидка 3 козячої вовни (переважно на Кавказі)'(СУМ 1: 258). Як свідчать вищезазначені матеріали, слово бу́рка є семантичним діалектизмом у всіх східностепових говірках, а в частині досліджуваних говірок (Св В, Бл В, Бз НА, Петр П) семантична структура номена зазнала подальших модифікацій в напрямку перенесення назви на основі подібності за призначенням та формою.

До інших типових видів метафоричних перенесень відносимо приклади перенесення за кольором. Наприклад, назву p'áбчик 'моряцька смугаста спідня сорочка, звичайно трикотажна' (М-Кач НА, Коз НА) - пор. укр. літ.: рябчик '1) лісовий птах родини тетерукових 3 рябим оперенням; 2) (Fritillaria, L.) рід багаторічних трав’янистих рослин родини лілійних 3 квітами різного забарвлення, переважно з рябим малюнком' (СУМ 8: 921). 
На особливу увагу в новостворених говірках заслуговують перенесення назви 3 наданням експресивної оцінки. Часто це відбувається при метафоричному перенесенні з неживого денотата на живий. Наприклад, номен $n e^{u} \mu^{\prime}{ }^{\prime} \kappa$ у досліджуваних говірках засвідчено не тільки як лексичний репрезентант семи 'нижня частина стовбура дерева, яка залишилась на корені після того, як дерево зрубали, спиляли', а й на позначення семи 'стара людина' (С M, С, Мих П) Порівняймо: а тут оста́нуи': а так'і́ стар'ї пе н'ки́ / йак оце́ ми / кому́ ми ну́жн'i // (C).

До таких же метафоричних перенесень $з$ експресивною оцінкою належать назви: йáзва ‘1) рана; 2) в 'їдлива людина' (в усіх східностепових говірках) - порівняймо укр. розм. язва 'ранка на шкірі або на слизовій оболонці (від поранення, хімічного ураження, інфекційного захворювання і т. ін.)' (СУМ 11: 627); шва́бра '1) пристрій для миття підлоги, виготовлений 3 держака та перпенликулярно прикріпленої вузької дощечки; 2) висока людина’ (в усіх східностепових говірках) - порівняймо укр. літ. шва́бра 'рід мітли з мачули, мотузків тощо, прикріплених до дерев'яної колодки, для миття, протирання підлоги, палуби і т. ін.' (СУМ 11: 426); мазни́u'a '1) посуд з розведеною глиною для мазання; 2) жінка в забрудненому одязі' (Красногор, С, Мих П) - пор. укр. літ. мазни́ия 'посуд для дьогтю' (СУМ 4: 595). Наприклад, вони́ приейіхали дес ' в об'і́d / а йа й не зна́ла / шо вони́ ж тут / та гр 'а́зна / ска́жут' / не б ба́ба / а мазни́и'а / полиева́ли са́ме // (C).

Метафоричні перенесення з експресивною оцінкою в східностепових говірках можливі і в межах моделей «неживе $\rightarrow$ неживе», «живе $\rightarrow$ живе». Так, назва лапс'орда́к (лапс'ерда́к, лапс'урда́к, лапсарда́к) 'ірон. назва будь-якого верхнього одягу’ (Шах Яс, С, Св В) відома досліджуваним говіркам і як репрезентант семи 'старовинний довгий верхній одяг'. В українській літературній мові це первинне і єдине значення (укр. літ. лапсердак 'старовинний довгий верхній одяг польських і галицьких євреїв’ (СУМ 4: 449)), а в деяких східностепових говірках воно вже втрачене (Мих П, Мар).

До перенесення з експресивною оцінкою належить і номен ке́н'd’yx, що вживається в говірках н. п. С, Зор, Корсунь як лексичний маніфестант сем 'начинений свинячий шлунок' (Омельченко, Клименко 2006: 44) i 'надмірно заповнений шлунок людини, яка звикла переїдати'. Наприклад, а йім н'ічо́го не тре́ба / аби́ m'íл'ки ке́н’d’ухи понабива́m' // (C). Маємо приклад метафоричного перенесення за спільністю враження, на яке накладається експресивне забарвлення. Порівняймо укр. літ. ке́ндюх '1) перший відділ шлунка жуйних тварин, у якому попередньо перетравлюється їжа; 2) начинений м'ясом і приготовлений як страва шлунок тварини; 3) зневажл. вайлувата людина' (СУМ 4: 140).

До метафоричних перенесень 3 експресивною оцінкою відносимо також записані М. Кушмет сільськогосподарські номени - лексичні репрезентанти семи 'шкідник': собаи' 'у́ра (Олексіївка ВН) і гад (Н-кат Ст, Н-петр ВН), що «передають негативне ставлення діалектоносіїв до шкідників, здатних сильно пошкодити врожай» (Кушмет-Бодаммер 2017: 109).

Наведений матеріал дозволяє стверджувати, що метафоричні перенесення в лексиці східностепових говірок відбуваються за типовими моделями і $є$ не тільки внутрішньосистемними (в межах одного семантичного поля), а й полісистемними (належність до різних семантичних полів).

Цікаво, що зменшено-пестливий варіант проаналізованої вище лексеми ши́йа - ши́йка також $є$ полісемічною назвою, належить до різних семантичних полів: 'назви частин тіла людини' та 'назви їжі', але виник уже внаслідок метонімічного перенесення. Так, у говірках н. п. С, Красногор, Петр П, Мих П назва шиийка, крім загальновідомого значення, уживається також як репрезентант семи 'очищена, промита й проварена гусяча шия, начинена шматочками м'яса'.

Аналіз типів лексичної полісемії в досліджуваних українських говірках підтверджує тезу Т. С. Коготкової про те, що метонімічні перенесення посідають чи не найпомітніше місце серед семантичних змін у діалектному слові (Коготкова 1977: 197). Метонімічні перенесення назв спостерігаємо в різних тематичних групах лексики донецьких говірок. Наприклад, серед лексем на позначення їжі, поширених у східностепових говірках, це описова назва рис з 
йáблуками 'рисова каша, тушена з яблуками, з додаванням вершкового масла, цукру, іноді родзинок’ (С, Грод, С М, Мих П), яка виникла внаслідок перенесення назви продуктів, з яких готують страву на саму страву.

Із сільськогосподарської лексики до метонімічних перенесень відносимо назви овс 'áнка, пшоно́. Так, лексема овс 'áнка (в 'івса́нка) в досліджуваних говірках виступає лексичним репрезентантом сем: 'вівсяна солома' (Іванівське, НК Амв, Яс Яс), 'вівсяне борошно' (Іванівське, НК Амв, Яс Яс, Гр М, Микіл В, Ст-мих М, Сів, ), 'вівсяна каша' (в усіх досліджуваних говірках). У більшості східностепових говірок назва пшоно́ є репрезентантом семи 'крупа з проса', а в деяких східностепових говірках ще й маніфестує сему 'просо (Panicum miliaceum L.)' (Андр В, Бл Амв, Н-петр ВН, Олексіївка ВН, Ст-дуб, Ст Ш, Ямп Л).

Серед метонімічних перенесень у східностепових говірках увагу привертає назва огурици не тільки, як репрезентант сем: 'овочева городня рослина родини гарбузових із сланким стеблом і невеликими довгастими плодами', ‘довгастий зелений плід цієї рослини', а й репрезентант семи 'стебла й листя огурців' (Укр НА). Порівняймо: позгр 'іба́в огуриии з горо́ду

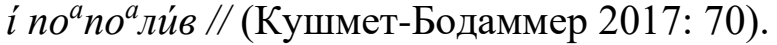

До метонімічних перенесень належить і відомий багатьом південно-східним говорам номен йázода, що функціонує в цій частині українського діалектного континууму як репрезентант сем 'соковитий, невеликого розміру плід трав'яних та кущових рослин (загалом)' та 'вишня', що свідчить про перенесення назви з цілого на частину. Подібне перенесення спостерігається і в номенах изи бу́л' $а$ (C), цииебу́л'ка (Дер Л), з 'ел'о́на ци бу́л 'ка (Ст Ш). У н.пп. Дер Л, Зол Ш, С на позначення семи 'листя молодої цибулі' зафіксовані назви циеббул' $a(\mathrm{C})$, цииебу́л'ка (С, Дер Л), з’іл'о́ний лук (Зол Ш), у семантичній структурі яких на перше місце виходить саме сема 'листя', що є свідченням метонімічного перенесення назви цілого на частину. В обстежених говірках зазначені номени вживаються і як репрезентанти семи 'головка цибулі разом з листям' Подібна зміна відбувається в східностепових говірках і з номеном часничи́на. Так, у говірці н. п. Уманське Ясинуватського району Донецької області метонімічних перетворень зазнала семантична структура назви часничи́на, що лексично маніфестує не тільки сему 'головка часнику', а й уживається на позначення семи 'один зубок часнику'(Ум Яс).

Не менш поширеними в досліджуваних говірках є перенесення назв з частини предмета на весь предмет, тобто синекдоха. Прикладами подібних перенесень серед назв одягу є: зако́m - уживається як лексичний репрезент сем 'відгорнутий, закочений назовні край чогонебудь (одягу, взуття, убрання і т. ін.)' і 'верхній зимовий одяг рівного крою, з овечої шкіри, 3 широким виложистим коміром' (Н-петр ВН), стр’ónйа - як репрезентант сем 'вистрьопані нитки в поношеному, старому одязі' та 'старий одяг' (Н-птр ВН).

У сільськогосподарській лексиці прикладами синекдохи є: m’ánка (Бл Амв, Петр В), canáчка (Стмйр ВН) у говірках н. п. Бл Амв, Петр В, Стмйр ВН репрезентують семи: 'ручне сільськогосподарське знаряддя для підпушування грунту й знищення бур'яну, яке являє собою металеву лопатку, насаджену перпендикулярно на дерев’яний держак' та 'жінка, яка обробляє просапані культури'.

У деяких східностепових говірках ( $С$ В, Рівнопіль, С, Ст-дуб) уживається назва кача́н як репрезентант не тільки семи 'потовщене стебло суцвіття кукурудзи, на якому росте ії насіння', а й 'рослина родини злакових, що має грубе високе стебло та їстівні зерна, зібрані в качан' Порівняймо: ми вже посади́ли качани́ в и’ом году́ / йак'í там сорта́ / одн'í вони́ / качани́ та й ycé // (Рівнопіль). Номен кача́н, співвідносний із семою 'загальна назва кукурудзи (рослина)', відомий і західнополіських українським говіркам (СЗГ 1: 214).

До східностепових назв їжі з розширеною семантичною структурою за рахунок перенесення назви частини на ціле належить і лексема заква́ска. Так, у деяких донецьких говірках ця назва $є$ репрезентантом сем 'речовина, що викликає кисле бродіння' та 'топлене незбиране молоко, заквашене сметаною” (Зл В, Новоукр, СВ НА, 7, Ол-Ор Ш, Арт Амв, Ст Ш, Гл Ст, Кум Ст). 
Висновки та перспективи дослідження. Таким чином, аналіз явища лексичної полісемії в східностепових говірках свідчить про активні зміни в семантичній структурі лексики новостворених говорів. 3-поміж таких змін регулярним виявляється ускладнення семантичної структури відомих іншим діалектам номенів через розвиток нових значень у результаті метафоричного чи метонімічного перенесення.

Вищенаведені матеріали дають підстави виділити такі особливості лексичної багатозначності східностепових говірок Донеччини: частиномовна належність слова не впливає на розвиток додаткових значень (сапа́чка, ви́св 'aтu $m$ '); нові значення можуть розвиватися в семантичній структурі як загальновідомих назв (ииебб́л'a, ши́йа, часни чи́на), так і вузьколокальних номенів (украйінс'кий бана́н); не менших зрушень зазнає семантична структура східностепових назв, що потрапили до словника української говірки пізнього творення 3 говірок інших мов (матр'óшка, зага́шни $е)$; однаково продуктивними виявляються в обстежуваних говірках метафоричні й метонімічні перенесення; серед метонімічних перенесень чи не найпродуктивнішою виявляється синекдоха (сапа́чка 'жінка, яка обробляє просапані культури '); метафоричні та метонімічні перенесення в східностепових говірках можливі за різними моделями: «неживе $\rightarrow$ неживе», «живе $\rightarrow$ живе», «неживе $\rightarrow$ живе», «живе $\rightarrow$ неживе» - і в межах різних терміносистем; особливої уваги заслуговують випадки розвитку полісемії з наданням експресивної оцінки.

Явище лексичної полісемії, розглянуте в межах окремих говірок, дозволяє в перспективі якнайточніше вибудувати наддіалектні моделі семантичної структури діалектних номенів для виявлення особливостей семантичного варіювання та напрями таких семантичних зрушень.

У статті охоплено лише незначну частину номенів з модифікованою семантичною структурою, проте проаналізований матеріал засвідчує, що такі назви $є$ в різних тематичних групах лексики і їх чимало. Причому зміни семантики діалектного слова передбачають не тільки розширення його семантичного обсягу. Поетапний аналіз усіх змін якомога більшої кількості полісемічних назв дозволить простежити напрями й характер семантичних змін лексики зазначеної частини українського діалектного континууму.

\section{Література}

Аркушин, Г. Л. Народна лексика Західного полісся: монографія. Луцьк: Східноєвропейський національний університет ім. Лесі Українки, 2014.

[Arkushyn, H.L. Narodna leksyka Zakhidnoho polissya: monohrafiya. Luts'k: Skhidnoyevropeys'kyy natsional'nyy universytet im. Lesi Ukrayinky, 2014.]

Бернштейн, С. Б. Размышления о славянской диалектологии. Славянское и балканское языкознание. Проблемь диалектологии. Категория посессивности. М.: Наука, 1986, 3-10.

[Bernshteyn, S. B. Razmyshleniya o slavyanskoy dialektologii. Slavyanskoye $i$ balkanskoye yazykoznaniye. Problemy dialektologii. Kategoriya posessivnosti. M.: Nauka, 1986, 3-10.]

Ващенко, В. С. До вивчення семантики діалектних слів. Пращі ХРесn. діал. наради. Київ, 1961, $17-25$.

[Vashchenko, V. S. Do vyvchennya semantyky dialektnykh sliv. Pratsi Kh Resp. dial. narady. Kyyiv, 1961, 17-25.]

Гримашевич, Г. І. Структура полісемічних назв одягу в середньополіських говірках. Вісник Житомирського державного університету імені Івана Франка 14. Житомир, 2004: 163-167.

[Hrymashevych, H. I. Struktura polisemichnykh nazv odyahu v seredn'opolis'kykh hovirkakh. Visnyk Zhytomyrs'koho derzhavnoho universytetu imeni Ivana Franka 14. Zhytomyr, 2004: 163167.]

Гриценко, П. Ю. Ареальне варіювання лексики. К.: Наук. думка, 1990.

[Hrytsenko, P. Yu. Areal'ne variyuvannya leksyky. K.: Nauk. dumka, 1990.]

Дзендзелівський, Й. О. Практичний словник семантичних діалектизмів Закарпаття. Ужгород, 1958. 
[Dzendzelivs'kyy, Y. O. Praktychnyy slovnyk semantychnykh dialektyzmiv Zakarpattya. Uzhhorod, 1958.]

Клименко, Н. Б. Локалізми в східностепових говірках Донеччини. [В]: Мовознавчий вісник 26. Черкаси, 2019, 81-89.

[Klymenko, N. B. Lokalizmy v skhidnostepovykh hovirkakh Donechchyny. [V]: Movoznavchyy visnyk 26. Cherkasy, 2019, 81-89.]

Коготкова, Т. С. Семантические заметки (К проблеме освоения литературной лексики в современных говорах). [В]: Диалектологические исследования по русскому языку. М.: Наука, 1977, 194-208.

[Kogotkova, T. S. Semanticheskiye zametki (K probleme osvoyeniya literaturnoy leksiki v sovremennykh govorakh). [V]: Dialektologicheskiye issledovaniya po russkomu yazyku. M.: Nauka, 1977, 194-208.]

Кушмет, М. С. Сільськогосподарська лексика українських східностепових говірок: автореф. дис. на здобуття наук. ступеня канд. філол. наук: спец. 10.02.01. Донецьк, 2014.

[Kushmet, M. S. Sil's'kohospodars'ka leksyka ukrayins'kykh skhidnostepovykh hovirok: avtoref. dys. na zdobuttya nauk. stupenya kand. filol. nauk: spets. 10.02.01. Donets'k, 2014.]

Кушмет-Бодаммер, М. С. Діалектологічний портрет Донеччини: кінець 2014 p. (сільськогосподарська лексика) Тернопіль: Крок, 2017.

[Kushmet-Bodammer, M. S. Dialektolohichnyy portret Donechchyny: kinets' 2014 r. (sil's'kohospodars'ka leksyka) Ternopil': Krok, 2017.]

Омельченко, 3. Л., Клименко, Н. Б. Матеріали до словника східностепових українських говірок. Донецьк: Вид-во ДонНУ, 2006.

[Omel'chenko, Z. L., Klymenko, N. B. Materialy do slovnyka skhidnostepovykh ukrayins'kykh hovirok. Donets'k: Vyd-vo DonNU, 2006.]

Русанівський, В.М. Структура лексичної і граматичної семантики. К.: Наук. думка, 1988.

[Rusanivs'kyy, V.M. Struktura leksychnoyi i hramatychnoyi semantyky. K.: Nauk. dumka, 1988.]

Старычонак, В. Д. Семантычная структура мнагазначнага слова ў дыялектнай мове. [B]: Studia z filologii polskiej i stowiańskiej 22. Warszawa:PWN, 1984, 189-195.

[Starychonak, V. D. Syemantychnaya struktura mnahaznachnaha slova w dyyalyektnay movye. [V]: Studia z filologii polskiej i słowiańskiej 22. Warszawa:PWN, 1984, 189-195.]

Тараненко, О. О. Лексична полісемія у живому мовленні села Олефірівки. [В]: Украӥнська народна лексика: Сб. науч. работ. Дніпропетровськ, 1973, 92-102.

[Taranenko, O. O. Leksychna polisemiya u zhyvomu movlenni sela Olefirivky. [V]: Ukrayins 'ka narodna leksyka: Sb. nauch. rabot. Dnipropetrovs'k, 1973, 92-102.]

Тищенко, Т. М. Дослідження семантики архаїчних лексем у діалектному просторі. [В]: Науковий вісник Херсонського державного університету. Серія «Лінгвістика»: зб. наук. пр. Херсон: Вид-во ХДУ, Вип. VII. 2008, 300-304.

[Tyshchenko, T. M. Doslidzhennya semantyky arkhayichnykh leksem u dialektnomu prostori. [V]: Naukovyy visnyk Khersons'koho derzhavnoho universytetu. Seriya»Linhvistyka»: zb. nauk. pr. Kherson: Vyd-vo KhDU, Vyp. VII. 2008, 300-304.]

Фроляк, Л. Д. Українські східностепові говірки Донеччини: монографія. Дрогобич: Просвіт, 2013.

[Frolyak, L. D. Ukrayins'ki skhidnostepovi hovirky Donechchyny: monohrafiya. Drohobych: Prosvit, 2013.]

Шматко, І. В. Полісемія в українській бджільницькій термінології. Українська мова 2, 2014: $75-82$.

[Shmatko, I. V. Polisemiya v ukrayins'kiy bdzhil'nyts'kiy terminolohiyi. Ukrayins'ka mova 2, 2014: 75-82.] 


\section{Використані джерела}

Ожегов - Ожегов С. И., Шведова Н. Ю. Толковый словарь русского языка: 80000 слов и фразеологических выражений / Российская Академия Наук. Институт русского языка им. В. В. Виноградова. 4-е изд., дополненное. М.: Азбуковник, 1999.

СЗГ - Аркушин Г. Л. Словник західнополіських говірок : у 2 т. Луцьк : Вежа, 2000. Т. 1-2.

СУМ - Словник української мови: В 11-и т. К.: Наук. думка, 1970-1980.

\section{Індекс обстежених населених пунктів Донецької області}

(назви населених пунктів і районів подано станом на 2020 рік)

Арт Амв - Артемівка Амвросіївського району, Андр В - Андріївка Волноваського району, Андр ВН - Андріївка Великоновосілківського району, Бз НА - Безіменне Новоазовського району, Бл Амв - Благодатне Амвросіївського району, Бл В - Благодатне Волноваського району, Вільне Вільне Волноваського району, Воздв - Воздвиженка Покровського району, ВП ВН - Вільне Поле Великоновосілківського району, Гл Ст - Глинки Старобешівського району, Гр - Гришине Покровського району, Грод - Гродівка Покровського району, Гр $\mathbf{M}$ - Григорівка Мар'їнського району, Дер Л - Дерилове Лиманського району, Дон В - Донське Волноваського району, $\mathbf{C ~ B ~ - ~}$ Сгорівка Волноваського району, $\mathbf{C}$ М - Слизаветівка Мар'їнського району, Зв Бахм - Званівка Бахмутського району, Зл В - Златоустівка Волноваського району, ЗК Добр - ЗолотийКолодязь Добропільського району, Зол Ш - Золотарівка Шахтарського району, Зор П - Зоряне Покровького району, Коз НА - Козацьке Новоазовського району, Корсунь - Корсунь м. Снакієвого, Іванівське - Іванівське Бахмутського району, Красногор - Красногорівка Мар'їнського району, Кр Ст - Краснопілля Старобешівського району, Кум Ст - Кумачеве Старобешівського району, Мар - Мар'їнка, Мик Г - Микитівка м. Горлівки, Микіл В - Микільське Волноваського району, М-Кач НА - М -Качкари Новоазовського району, Мих П - Михайлівка Покровського району, Н-ап В - Новоапостолівка Волноваського району, Н-бах Яс - Новобахмутівка Ясинуватського району, Н-кат Ст - Новокатеринівка Старобешівського району, НК Амв Нижня Кринка Амвросіївського району, Новотр В - Новотроїцьке Волноваського району, Н-петр ВН - Новопетриківка Великоновосілківського району, Новоукр - Новоукраїнка Мар'їнського району, Ол В - Оленівка Волноваського району, Олексіївка ВН - Олексіївка Великоновосілківського району, Ол-Ор Ш - Олексієво-Орлівка Шахтарського району, Оп Яс Опитне Ясинуватського району, Ор Яс - Орлинське Ясинуватського району, Перв Яс Первомайське Ясинуватського району, Петр В - Петрівка Волноваського району, Петр П Петрівка Покровського району, Рівнопіль - Рівнопіль Волноваського району, Роя - Роя Мар'їнського району, РЯ Кост - Русин Яр Костянтинівського району, Св В - Свободне Волноваського району, СВ НА - с. Сєдово-Василівка Новоазовського району, Сел - Селидове, Сів - Сіверськ Бахмутського району, Ст В - Степне Волноваського району, Ст Ш - Степанівка Шахтарського району, Стмйр ВН - Старомайорське Великоновосілківського району, Ст-дуб Стародубівка Мангушського району, Ст-мих М - Старомихайлівка Мар'їнського району, Укр НА - Українка Новоазовського району, Ум Яс - Уманське Ясинуватського району, Шах Яс Шахова Ясинуватського району, Шевч ВН - Шевченко Великоновосілківського району, Ямп Л Ямпіль Лиманського району, Яс Яс - Ясинівка Ясинуватськогорайону.

\section{LEXICAL POLYSEMY IN UKRAINIAN EASTERN STEPPE DIALECTS Nataliya Klymenko}

Language Training Department, Donetsk National Technical University, Pokrovsk, Ukraine

Background: The study of the dialect semantics remains one of the most relevant tasks of modern linguistics. At the present stage of Ukrainian dialectology, the issues of semasiology on the material of different lexical groups are raised in the research on ancient Ukrainian dialects. However, there is still no clear idea of the semantic changes that occur in the newly created Ukrainian dialects, in particular the Eastern Steppe dialects of Donetsk region, which determines the relevance of the 
study.

Purpose: The aim of the article is to analyse the phenomenon of lexical polysemy in Ukrainian Eastern Steppe dialects.

Results: polysemantic vocabulary of Donetsk dialects is characterized by the following features: the word part-of-speech affiliation does not affect the development of additional meanings; new meanings can develop in the semantic structure of both well-known names and local names; the semantic structure of Eastern Steppe names, which came to the dialect dictionary from dialects of other languages, is also undergoing changes; metaphorical and metonymic transfers are equally productive in the dialects under study; synecdoche is perhaps the most productive among metonymic transfers; metaphorical and metonymic transfers in Eastern Steppe dialects occur according to different models: "inanimate $\rightarrow$ inanimate", "animate $\rightarrow$ animate", "inanimate $\rightarrow$ animate", "animate $\rightarrow$ inanimate" - and within different terminological systems; cases of polysemy development with expressive evaluation deserve special attention.

Discussion: analysis of lexical polysemy in Ukrainian Eastern Steppe dialects makes it possible to trace the semantic capacity of the dialect word in a newly created dialect; main tendencies of semantic structure development in Ukrainian Eastern Steppe dialects of late creation; to lay down potential meanings in the creation of a superdialect model - an invariant semantic structure of the analysed vocabulary, which will allow isolating typical and sporadic semantic changes in the lexical system of the Ukrainian dialect language. A step-by-step analysis of all changes in as many polysemantic names as possible will allow tracing the directions and nature of semantic changes in the vocabulary of this part of the Ukrainian dialect continuum.

Keywords: seme, word semantic structure, polysemy, metaphorical transfer, metonymic transfer, synecdoche, dialect vocabulary, Ukrainian Eastern Steppe dialects.

Vitae

Nataliya Klymenko is Associate Professor of Language Training Department in Donetsk National Technical University. Her areas of research interests include Ukrainian Dialectology, lexicography, dialect textography, lexicology, semasiology, phonetics.

Correspondence: klymenko2010@gmail.com

Надійшла до редакції 20 березня 2021 року

Рекомендована до друку 5 квітня 2021 року

Дар'я Козловська

ORCID: orcid.org/0000-0002-5731-5375

DOI 10.31558/1815-3070.2021.41.28

УДК $811.161 .2 ’ 372.21$

\section{ДО ПИТАННЯ ПРО ДЕКОДУВАЛЬНО-СМИСЛОВУ РОЛЬ ПРОТООНІМІВ ВЛАСНИХ НАЗВ ПОЕТИЧНИХ ТЕКСТІВ ЗБІРКИ В. СТУСА «ЧАС ТВОРЧОСТІ»}

3'ясовано протооніми власних назв поетичних текстів збірки В. Стуса "Час творчості». Встановлено концептуальні й смислові зв'язки між протоонімами й антро-, топо-, теопоетонімами в текстах. Констатовано, що встановлення ичих зв'язків сприяє декодуванню авторського світовідчуття та концепції віршованих текстів. Проаналізовано роль протоонімів у вербалізації ознак української ментальності в текстах збірки.

Ключові слова: протоонім, антропоетонім, топопоетонім, теопоетонім. 